\title{
KONSEP RIBA DALAM KOMPILASI HUKUM EKONOMI SYARI'AH (STUDI ANALISIS TEKS KHES INDONESIA)
}

\author{
Febrina Sari \\ BPRS Al-Makmur,febrinasari@gmail.com \\ Dahyul Daipon \\ LAINBukittinggi,dahyuldaipon@gmail.com
}

Diterima: 22 Juli $2018 \quad$ Direvisi : 13 November $2018 \quad$ Diterbitkan: 30 Desember 2018

\begin{abstract}
Economic and financial issues such as trade (tijarah), rent (ijarab), mortgage (rahn), accounts payable (mudayanab), wages to pay (ujrah) and others related to the basic norms of economic transactions are arranged all in Islam. Allab has reduced sustenance to this world to be used by bumans in a way that has been legalized by Allah SWT and is clean of all acts that contain usury. Usury is an additional requirement in a business transaction without the existence of iwadh (equivalent) which is justified by the shari'ah for the addition. Broadly speaking, usury is classified into two; usury of debt and usury debt buying and selling. Usury debt accounts are divided into two, namely; usury giradh and usury jabiliyah, while usury selling and buying is also divided into two, namely usury fadhal and riba nasi'ah. The rules relating to usury are also widely discussed by the jurists in their books. KHES is the actual form of Islamic law in Indonesia related to Islamic economic activities. So that with the presence of KHES, economic business actors carried out according to shari'ah principles if a dispute occurs, it can be resolved with this KHES reference. KHES has been used as a guideline that replaces Islamic law, namely the Qur'an and hadith. KHES is a syari'ah principle guideline source for Judges in the Religious Court and also for the Syari'ah Arbitration Agency in terms of resolving sharia economic disputes. The problem is that none of the KHES articles deal with usury. The word "usury" is only a few that can be found in this book of KHES. This is due, among others; First, KHES discusses the contracts in mu'amalah. While usury is not a contract. Second, KHES adopts some of the books of Majallah al Ahkam al 'Adliyyah of the Ottoman Turks so also there is no discussion regarding usury or interest. Third, avoiding usury is the principle of transactions / contracts in the Shari'ah. The position of usury is parallel with gharar, maisir and dharar which must also be avoided. Fourth, that in the treasury of Islamic law or figh it has been discussed / discussed in depth and wide, so that it is felt that there is no need to be raised (specifically discussed) in KHES.
\end{abstract}

Keywords: Konsep, Riba, KHES Indonesia

\begin{abstract}
Abstrak
Persoalan-persoalan ekonomi dan keuangan seperti perdagangan (tijarah), sewa menyewa (ijarab), gadai (rabn), utang piutang (mudayanab), upab mengupah (ujrah) dan lain sebagainya yang berbubungan dengan norma-norma dasar bertransaksi ekonomi diatur semuanya dalam Islam. Allah telah menurunkan rezeki ke dunia ini untuk dimanfaatkan oleh manusia dengan cara yang telah dihalalkan oleh Allah SWT dan bersih dari segala perbuatan yang mengandung riba. Riba adalah tambahan yang disyaratkan dalam transaksi bisnis tanpa adanya iwadh (padanan) yang dibenarkan oleh syari'at atas penambaban tersebut. Secara garis besar, riba digolongkan menjadi dua; riba utang piutang dan riba jual beli. Riba utang piutang dibagi lagi menjadi dua yaitu; riba qiradh dan riba jabiliyah, sedangkean riba jual beli terbagi juga kepada dua, yaitu riba fadhal dan riba nasi'ah. Aturan yang berkaitan dengan riba ini juga banyak dibahas oleh fuqaba' dalam kitab-kitabnya. KHES merupakan wujud aktual dari bukum Islam yang ada di Indonesia terkait kegiatan perekonomian Islam. Sehingga dengan adanya KHES, para pelaku usaha ekonomi yang dijalankan menurut prinsip syari'ab apabila terjadi sebuah sengketa, maka dapat diselesaikan dengan rujukan KHES ini. KHES telah dijadikan pedoman yang menggantikan Hukum Islam yakni al-Qur'an dan hadits. KHES merupakan sumber pedoman prinsip syari'ab bagi Hakim di Pengadilan Agama dan juga bagi Badan Arbitrase Syari'ah dalam hal penyelesaian sengketa ekonomi syari'ah. Permasalahannya adalah tidak satupun dari pasal KHES yang membahas mengenai riba. Kata "riba" pun banya sedikit
\end{abstract}




\begin{abstract}
yang dapat dijumpai dalam kitab KHES ini. Hal itu disebabkan antara lain; pertama, KHES membahas tentang akad-akad dalam mu'amalah. Sedangkan riba bukanlah merupakan suatu akad. Kedua, KHES mengadopsi sebagian kitab Majallah al Abkam al 'Adliyyah Turki Utsmani karenanya juga tidak ada pembahasan terkait riba ataupun bunga. Ketiga, terbindar dari riba merupakan prinsip transaksi/akad dalam syari'ah. Posisi riba sejajar dengan gharar, maisir dan dharar yang juga harus dibindari. Keempat, bahwa di dalam khazanah bukum Islam atan fikih sudah dibicarakan/dibahas secara mendalam dan luas, sehingga dirasa tidak perlu lagi dimunculkan (dibahas secara khusus) di dalam KHES.
\end{abstract}

Kata Kunci: Konsep, Riba, KHES Indonesia

\section{PENDAHULUAN}

Islam merupakan suatu agama yang lengkap (syumul) sehingga mempunyai konsep dan teori tentang berbagai macam aktifitas bagi para pemeluknya. Islam merupakan agama yang tidak hanya mengatur persoalan akidah dan ibadah, akan tetapi juga memberikan landasan utama tentang normanorma dasar dan etika dalam ber-mu'amalah. Persoalan-persoalan ekonomi dan keuangan seperti perdagangan (tijarah), sewa menyewa (ijarab), gadai (rabn), utang piutang (mudayanab), upah mengupah (ujrah) dan lain sebagainya yang berhubungan dengan norma-norma dasar bertransaksi ekonomi diatur semuanya dalam Islam.

Di dalam bingkai ajaran Islam, aktifitas ekonomi yang dilakukan oleh manusia untuk dikembangkan memiliki beberapa kaidah dan etika atau moralitas dalam syari'at Islam. Allah telah menurunkan rezeki ke dunia ini untuk dimanfaatkan oleh manusia dengan cara yang telah dihalalkan oleh Allah SWT dan bersih dari segala perbuatan yang mengandung riba.

Kata "riba" diambil dari kata "rabaayarbuu” yang berarti tambahan. ${ }^{1}$ Secara istilah, riba diartikan sebagai tambahan pada harta yang disyaratkan dalam transaksi dari dua pelaku akad dalam tukar menukar antara harta dengan harta. ${ }^{2}$ Tambahan yang dimaksud disini adalah tambahan atas modal, baik

1 Muhammad bin Ismail Al-Amir AshShan'ani, Subulus Salam Syarab Bulughul Maram, penerj. Muhammad Isnan, dkk,(Jakarta: Darus Sunnah Press, 2012), cet. ke-7, hal. 394.

2 Ahmad Sarwat, Kitab Mu'amalat, ([t.tp]: Kampus Syari’ah, 2009), hal. 21. penambahan itu sedikit ataupun banyak. Tambahan ini muncul dalam dua akad, baik jual beli maupun utang piutang.

Begitu banyak larangan mengenai riba yang terkandung di dalam al- Qur'an maupun hadis rasulullah SAW. Dalam Alquran antara lain terdapat pada surat al Baqarah ayat 275279:

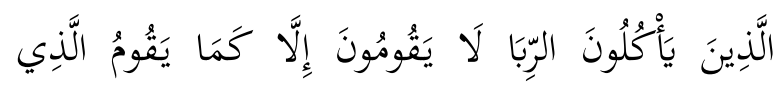

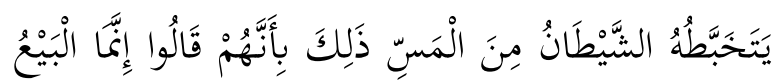

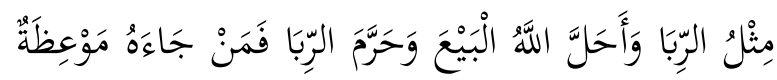

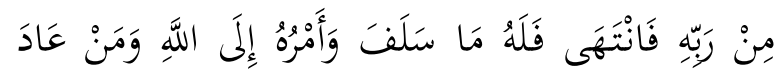

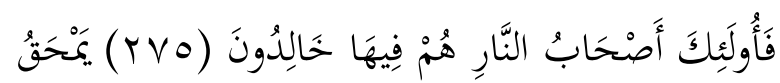

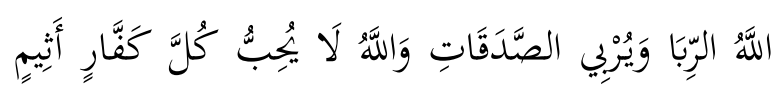

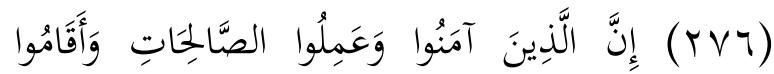

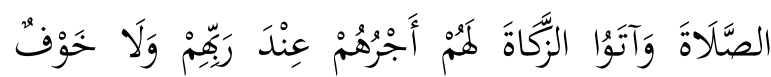

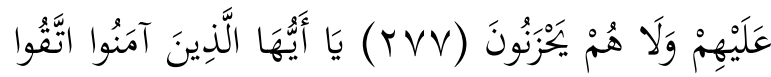

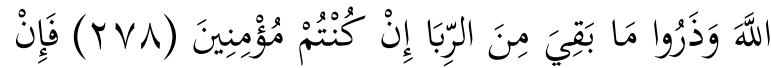

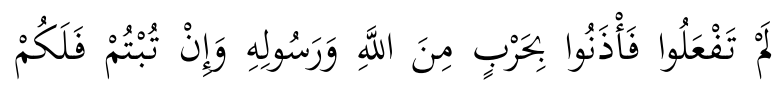

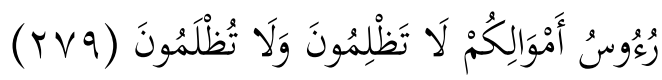
Orang-orang yang makan (mengambil) riba tidak dapat berdiri melainkan seperti berdirinya orang yang kemasukan syaitan lantaran (tekanan) penyakit gila. Keadaan mereka yang demikian itu, adalah disebabkan mereka berkata (berpendapat). Sesunggubnya jual beli itu sama dengan riba. Padabal Allah telah menghalalkan jual beli dan mengharamkan riba. Orang-orang yang telah sampai kepadanya larangan dari Tubannya, lalu terus berhenti (dari mengambil riba), maka baginya apa yang telah diambilnya dabulu (sebelum datang larangan); dan urusannya (terserab) kepada Allah. 
Orang yang kembali (mengambil riba), maka orang itu adalab penghuni-penghuni neraka; mereka kekal di dalamnya.(275) Allah memusnabkan riba dan menyuburkan sedekah dan Allah tidak menyukai setiap orang yang tetap dalam kekeafiran dan selalu berbuat dosa. 276. Sesungguhnya orang-orang yang beriman, mengerjakan amal saleh, mendirikan shalat dan menunaikan zakat, mereka mendapat pahala di sisi Tuhannya. Tidak ada kekhawatiran terhadap mereka dan tidak (pula) mereka bersedih hati. 277.Hai orang-orang yang beriman, bertakwalah kepada Allah dan tinggalkan sisa riba (yang belum dipungut) jika kamu orang-orang yang beriman. 278.Maka jika kamu tidak mengerjakan (meninggalkean sisa riba), maka ketahuilah, babwa Allah dan Rasul-Nya akan memerangimu dan jikea kamu bertaubat (dari pengambilan riba), maka bagimu pokok hartamu; kamu tidak menganiaya dan tidak (pula) dianiaya. 279.

Berdasarkan ayat di atas, dapat diambil pemahaman bahwa Islam dengan tegas dan pasti mengharamkan riba ini. Hal itu untuk menjaga kemaslahatan hidup manusia dari kerusakan moral (akhlak), sosial dan ekonominya. Dampak negatif yang diakibatkan dari riba sangat berbahaya bagi kehidupan manusia secara individu, keluarga, masyarakat dan berbangsa. Jika praktik riba ini tumbuh subur di masyarakat, maka terjadi sistem kapitalis dimana terjadi pemerasan dan penganiayaan terhadap kaum lemah. Orang kaya semakin kaya dan miskin semakin tertindas. $^{3}$

Di dalam pembahasan fikih mu'amalah dikenal adanya pembagian riba ke dalam dua golongan, yakni riba nasi'ah dan riba fadhal. Riba nasiah merupakan tambahan baik berupa tunai, benda, maupun jasa yang mengharuskan pihak peminjam untuk membayar selain jumlah uang yang dipinjamkan kepada pihak yang meminjamkan pada hari jatuh waktu mengembalikan uang pinjaman itu. Sedangkan riba fadhal ialah kelebihan yang terdapat dalam

${ }^{3}$ Abdul Rahman Ghazaly, dkk, Fiqh Mu'amalat, (Jakarta: Kencana Prenada Media Group, 2012), cet. Ke-2, hal. 222-223. tukar menukar antara benda-benda sejenis, seperti emas dengan emas, perak dengan perak. $^{4}$

Hukum materiil ekonomi syari'ah di Indonesia pada umumnya baru tersedia dalam bentuk fiqh rumusan para fuqaha', fatwa Dewan Syari'ah Nasional Majelis Ulama Indonesia (DSN MUI). Dengan kelahiran Undang-Undang No. 3 Tahun 2006 tentang Perubahan atas Undang-Undang No. 7 Tahun 1989 tentang Peradilan Agama yang telah disahkan oleh Presiden Republik Indonesia membawa implikasi besar terhadap perundang-undangan yang mengatur harta benda, bisnis, dan perdagangan secara luas.

Pada pasal 49 poin i disebutkan dengan jelas bahwa Pengadilan Agama bertugas dan berwenang memeriksa, memutus dan menyelesaikan perkara di tingkat pertama antara orang-orang yang beragama Islam di bidang ekonomi syariah. ${ }^{5}$ Bagi kepentingan penyelesaian sengketa ekonomi syari'ah di pengadilan, maka Mahkamah Agung RI menerbitkan PerMA nomor 02 tahun 2008 tentang Kompilasi Hukum Ekonomi Syari'ah (KHES). KHES ini terdiri dari 4 buku, masing-masing tentang Subjek Hukum dan Amwal, Akad, Zakat dan Hibah dan Akuntansi Syariah.

KHES merupakan wujud aktual dari hukum Islam yang ada di Indonesia terkait kegiatan perekonomian Islam, jika terjadi persengketaan di bidang ekonomi Islam. Sehingga dengan adanya KHES, para pelaku usaha ekonomi yang dijalankan menurut prinsip syari'ah apabila terjadi sebuah sengketa, maka dapat diselesaikan dengan rujukan KHES ini. KHES telah dijadikan pedoman yang menggantikan Hukum Islam yakni alQur'an dan hadits.

Dilihat dari kandungan isi KHES, dari 790 pasal, sejumlah 653 pasal (80\%)

\footnotetext{
${ }^{4}$ Ibid., hal. 218-220.

5 Zainuddin Ali, Hukum Ekonomi Syariah,
} (Jakarta: Sinar Grafika, 2008), hal. 13. 
adalah berkenaan dengan akad. Dengan demikian, materi terbanyak yang terdapat di dalam KHES berkaitan dengan akad. Jika diperhatikan cakupan bab dan pasal dalam KHES, maka dapat dikatakan bahwa ruang lingkup ekonomi syari'ah meliputi: ba'i, syirkah, mudharabah, muгara'ah, musaqqah, khiyar, ijarah, kafalah, hawalah, rahn, wadi'ah, ghasab dan ithlaf, wakalah, shulhu, pelepasan hak, ta'min, obligasi syari'ah, pasar modal, reksadana syari'ah, sertifikasi bank. Indonesia syari'ah, pembiayaan multi jasa, qardh, pembiayaan rekening koran syari'ah, dana pensiun syariah, zakat dan bibah, serta akuntansi syari'ab. $^{6}$

KHES merupakan sumber pedoman prinsip syari'ah bagi Hakim di Pengadilan Agama dan juga bagi Badan Arbitrase Syari'ah dalam hal penyelesaian sengketa ekonomi syari'ah. Tidak hanya itu, saat ini KHES telah dijadikan sebagai salah satu mata kuliah di Perguruan Tinggi Agama Islam, salah satunya di Fakultas Syari'ah IAIN Bukittinggi.

Dalam ajaran fikih mu'amalah tidak dibenarkan adanya riba dalam suatu akad yang dilaksanakan oleh para pihak. Makanya dalam fikih banyak sekali dijumpai pembahasan mengenai riba. KHES sebagai suatu kodifikasi hukum tentang ekonomi syari'ah yang mana saat ini telah dijadikan sebagai salah satu sumber dalam Hukum Ekonomi Syari'ah, namun tidak satupun dari pasal KHES yang membahas mengenai riba. Kata "riba" pun hanya sedikit yang dapat dijumpai dalam kitab KHES ini.

Berdasarkan realitas ini tentu menarik untuk membahas permasalahan; terkait dengan konsep riba di dalam KHES dan kenapa di dalam KHES, riba tidak dituangkan dalam bentuk pasal per pasal?.

${ }^{6}$ PPHIMM, Kompilasi Hukum Ekonomi Syari'ah, (Jakarta: Kencana Prenada Media Group, 2009), hal. xvxxvi.

\section{PENGERTIAN RIBA}

Riba menurut bahasa berasal dari kata "rabaa-yarbuu” yang berarti ziyadah (tambahan, bertambah atau tumbuh), pertumbuhan (growth), naik (rise), membengkak (swell), bertambah (increase), tambahan (additional), berkembang (an numuw), meningkat (al irtifa), membesar (al 'uluw).

Maksud riba dalam ayat Alquran, yaitu setiap penambahan yang diambil tanpa adanya satu transaksi pengganti atau penyeimbang yang dibenarkan oleh syari'ah.Transaksi pengganti atau penyeimbang dimaksud, yaitu transaksi bisnis atau komersial yang melegitimasi terhadap penambahan tersebut secara adil. Seperti transaksi jual beli, gadai, sewa, atau bagi hasil proyek. Dalam transaksi sewa, si penyewa membayar upah sewa karena adanya manfaat sewa yang dinikmati, termasuk menurunnya nilai ekonomis suatu barang karena penggunaan si penyewa. Mobil misalnya, sesudah dipakai nilai ekonomisnya pasti menurun, jika dibandingkan sebelumnya. Dalam hal jual beli si pembeli membayar harga atas imbalan barang yang diterimanya. Demikian juga dalam proyek bagi hasil, para peserta perkongsian berhak mendapat keuntungan karena di samping menyertakan modal juga turut sarta menanggung kemungkinan resiko kerugian yang bisa saja muncul setiap saat. ${ }^{8}$

Abu Sura'i Abdul Hadi dalam pembahasannya mengenai riba menjelaskan bahwa para ahli fikih berbeda pendapat dalam pendefinisian riba. Sesuai dengan pengertian masing-masing menurut sebab penetapan haramnya: ${ }^{9}$

${ }^{7}$ Abd. Shomad, Hukum Islam: Penormaan Prinsip Syariah dalam Hukum Indonesia Edisi Revisi, (Jakarta: Kencana Prenada Media Group, 2012), hal. 94.

8 Zainuddin Ali, Hukum Perbankan Syari'ah, (Jakarta: Sinar Grafika, 2010), hal. 89-90.

${ }^{9}$ Abu Sura'i Abdul Hadi, Bunga Bank dalam Islam terjemahan dari Ar Riba wal Qurudl, (Surabaya: Al Ikhlas, 1993), hal. 24. 
Mazhab Hanafi mendefinisikan riba sebagai setiap kelebihan tanpa adanya imbalan pada takaran dan timbangan yang dilakukan antara pembeli dan penjual di dalam tukar menukar. Misalnya menukar dirham dengan berat yang tidak sama, hal ini dibolehkan karena dipandang hibah. Jadi mereka menetapkan kelebihan penukaran itu riba apabila barangnya sejenis.Alasan mereka ialah hadits-hadis dari rasulullah SAW yang menyatakan jual beli emas dengan emas, perak dengan perak, gandum dengan gandum, beras dengan beras, serupa dan sepadan serta tunai. Penetapan syarat semacam ini menunjukkan adanya keharusan ukuran dan kadar yang sama dan dilakukan di suatu tempat. Jika salah satu syarat ini tidak terpenuhi karena beratnya tidak sama, maka transaksi semacam ini tidak bersifat ribawi. ${ }^{10}$

Mazhab Syafi'i, riba adalah transaksi dengan imbalan tertentu yang tidak diketahui kesamaan takarannya maupun ukuran waktu dilakukan transaksi atau dengan penundaan waktu penyerahan kedua barang yang dipertukarkan atau salah satunya. Kesamaan takaran atau ukuran yang dimaksud disini adalah pada barang sejenis, seperti emas dengan emas, sedangkan penundaan waktu penyerahan boleh jadi harga dari salah satu barang itu telah berubah harganya. Sehingga pertukaran semacam ini mengandung sifat riba. Sebab larangan ini berlakunya pada barang makanan sekalipun barang tersebut pengukurannya menggunakan takaran atau timbangan dan dilakukan tidak secara tunai. Bila pertukaran dilakukan pada barang sejenis, seperti beras dengan beras, maka berlaku larangannya dalam tiga hal: kelebihan timbangan atau takaran, pada tempo dan pada perginya kedua belah pihak sebelum serah terima barang. Bila sama-sama bahan makanan, tetapi berbeda jenis seperti gandum dengan beras, maka dibolehkan adanya

${ }^{10}$ Ibid., hal. 24. kelebihan tukar, tetapi diharamkan adanya tempo penyerahan dan berpisah sebelum keduanya menerima barangnya. ${ }^{11}$ Alasan mereka bahwa larangan tersebut berlakunya pada barang yang sama adalah hadis Ubadah bin Shamid berikut ini:

وَعَنْ عُبَادَةَ بْنْ الصَّامِتِ قَالَ: قَالَ رَسُولُ المَِّّ صَلَّى اللَّهُ

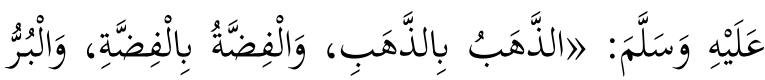

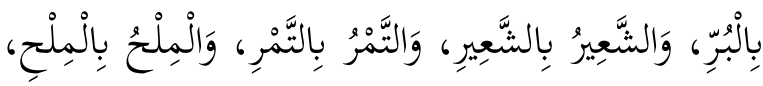

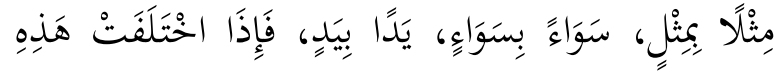

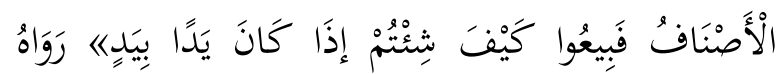

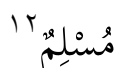

Dari Ubadah bin Ash-Shamit Radhiyallahu Anbu babwa Rasulullab Shallallabu Alaibi wa Sallam bersabda, "(Diperbolehkan menjual) emas dengan emas, perak dengan perak, gandum dengan gandum, sya'ir dengan sya'ir, kurma dengan kurma, garam dengan garam, sama sebanding, sejenis, dan ada serah terima dan jika jenis-jenisnya berbeda maka juallab sesuai dengan kehendak kalian dengan syarat kontan." (HR. Muslim).

Mazhab Maliki definisinya hampir sama dengan definisi golongan Syafi'i hanya berbeda pada illat-nya, yakni pada transaksi tidak kontan pada bahan makanan yang tahan lama. Yang dimaksud illat kontan yaitu barang yang bernilai seperti pendapat golongan Syafi'i. Termasuk dalam kategori bahan makanan yang dapat disimpan adalah buah-buahan, seperti: semangka, kentang dan sejenis ubi-ubian. Sedangkan buah yang biasa dipakai untuk obat-obatan, menurut golongan ini tidak termasuk barang ribawi. Begitu pula bahan makanan yang tak tahan lama seperti kacang panjang. Tetapi mereka mengkategorikan barang riba gandum dengan beras dalam satu jenis. Karena kedua bahan makanan tersebut

\footnotetext{
${ }^{11}$ Ibid., hal. 24-25.

12 Muhammad bin Ismail al Amir ash Shan'ani, Subul al-Salam Syarah Bulughul Maram, penerj. Muhammad Isnan, dkk, (Jakarta: Darus Sunnah Press, 2012) hal. 398.
} 
kegunaannya serupa, namun dengan syarat takaran dan timbangannya sama dan penyerahan seketika. ${ }^{13}$

Mazhab Hanbali, riba adalah tambahan yang diberikan pada barang tertentu, yakni barang yang dapat ditukar atau ditimbang dengan jumlah yang berbeda. Tindakan semacam inilah yang dinamakan riba, selama dilakukan dengan tidak kontan. Tetapi kalau barangnya sejenis, seperti gandum dengan gandum yang sebanding dan dengan penyerahan kontan, baru dinamakan riba kalau ada kelebihan. Tetapi kalau berlainan jenis misalnya gandum dengan beras dibolehkan adanya kelebihan sekalipun penyerahannya kontan. Definisi lainnya yaitu kelebihan pertukaran barang tertentu dan penyerahannya bertempo pada barang-barang yang bisa ditimbang atau ditakar. ${ }^{14}$

Menurut istilah teknis, riba berarti pengambilan tambahan dari harta pokok atau modal secara bathil. Ada beberapa pendapat dalam menjelaskan riba, namun secara umum terdapat benang merah yang menegaskan bahwa riba adalah pengambilan tambahan, baik dalam transaksi jual beli maupun pinjam meminjam secara bathil atau bertentangan dengan prinsip mu'amalat dalam Islam. ${ }^{15}$

Mengenai hal ini Allah mengingatkan dalam Alquran Surat an-Nisa' (4) ayat 29 sebagai berikut:

يَا أَيْهَها اللَّذِينَ آحَنُوا لَ نَأْكُلُوا أَمْوَالَكُمْ بَيْنَكُمْ بِالْبَاطِلِ

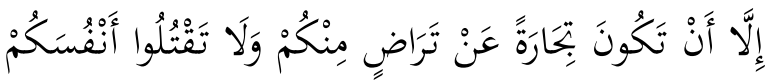

$$
\text { إِنَّ اللَََّكَانَ بِكُمْ رَحِيمًا }
$$

Hai orang-orang yang beriman, janganlab kamu saling memakan harta sesamamu dengan jalan yang batil, kecuali dengan jalan perniagaan yang berlaku dengan suka sama-suka di antara kamu dan janganlah kamu membunub dirimu. Sesunggubnya Allab adalah Maha Penyayang kepadamu.

\footnotetext{
${ }^{13}$ Ibid., hal.25.

${ }^{14}$ Ibid., hal.26.

${ }^{15}$ Zainuddin Ali, Op.,Cit.,hal. 88.
}

Berbicara riba identik dengan bunga bank atau rente, sering terdengar di tengahtengah masyarakat bahwa rente disamakan dengan riba. Sebab, rente dan riba merupakan bunga uang, karena mempunyai arti yang sama yaitu sama-sama bunga, maka hukumnya sama yaitu haram.

\section{DALIL PENGHARAMAN RIBA}

\section{Ayat Alquran}

Anti-riba merupakan konsep yang diturunkan dari Alquran dan hadis Rasulullah SAW. Alquran dengan jelas menggunakan kata riba sebanyak delapan kali yang terdapat dalam empat surat, yaitu al Baqarah, Ali Imran, an Nisa', dan ar Ruum. Tiga surat pertama termasuk dalam surat Madaniyyah yang turun setelah Nabi Muhammad SAW hijrah ke Madinah. Sedangkan surat ar Ruum masuk dalam surat Makkiyah yaitu turun sebelum beliau hijrah. Dengan begitu, ayat pertama yang berbicara tentang riba adalah ar Ruum: 39. Terhapusnya riba dalam ekonomi Islam dipaparkan oleh Alquran secara bertahap yaitu QS. Ar Ruum: 39, QS. An Nisa': 160-161, QS. Ali Imran: 130 dan QS. Al Baqarah: 275-279. ${ }^{16}$

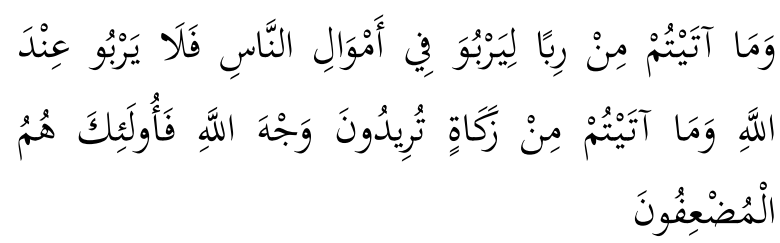

"Dan sesuatu Riba (tambahan) yang kamu berikan agar dia bertambah pada harta manusia, maka Riba itu tidak menambah pada sisi Allah. Dan apa yang kamu berikan berupa zakat yang kamu maksudkan untuk mencapai keridhaan Allah, maka yang berbuat demikian) itulah orang-orang yang melipat gandakan (pahalanya).” QS. Ar-Ruum: 39

Pada tahap pertama ini, peringatan Allah SWT dalam Alquran mengenai riba adalah menolak anggapan bahwa pinjaman

${ }^{16}$ Dwi Suwiknyo, Kompilasi Tafsir Ayat-Ayat Ekonomi Islam, (Yogyakarta: Pustaka Pelajar, 2010), hal. 36. 
yang pada zahir-nya seolah-olah menolong mereka yang memerlukan sebagai suatu perbuatan mendekati atau taqarrub kepada Allah SWT. ${ }^{17}$

Perbandingan antara riba dan zakat menunjukkan bahwa riba terkesan mengambil harta orang lain tanpa ada transaksi penyeimbang, sedangkan zakat memberikan harta kepada orang lain sebagai wujud kepedulian. Keduanya dapat melipatgandakan, riba melipatgandakan harta sedangkan zakat melipatgandakan pahala karena sifat kesalehan sosial orang yang berzakat. ${ }^{18}$

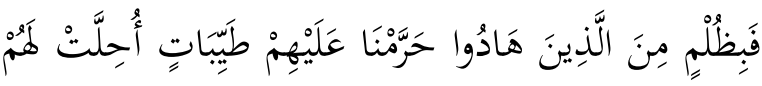

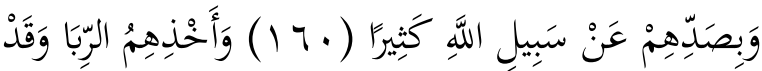

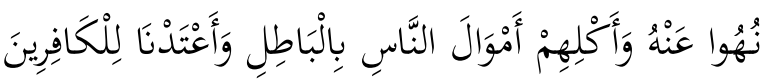

$$
\text { مِنْهُمْ عَذَاَبًا أَلِيمًا (1) }
$$

Maka disebabkan kezaliman orang-orang Yabudi, Kami haramkan atas mereka (memakan makanan) yang baik-baik (yang dabulunya) dibalalkan bagi mereka dan karena mereka banyak menghalangi (manusia) dari jalan Allah.(160).Dan disebabkan mereka memakan riba, padahal sesunggubnya mereka telah dilarang daripadanya, dan karena mereka memakan harta benda orang dengan jalan yang batil. Kami telah menyediakan untuk orang-orang yang kafir di antara mereka itu siksa yang pedih. (161). QS. An Nisa': 160-161

Pada tahap kedua, peringatan Allah SWT dalam Alquran mengenai riba digambarkan sebagai suatu yang buruk. Allah SW'T mengancam akan memberi balasan yang keras kepada orang Yahudi yang memakan riba. ${ }^{19} \mathrm{Hal}$ ini karena dipandang memakan harta orang lain secara bathil. Ayat-ayat tersebut menerangkan bahwa Allah akhirnya mengharamkan makanan yang dulunya dihalalkan bagi mereka. Pengharaman tersebut dilakukan karena perilaku zalim orang-orang
Yahudi kepada sesama manusia. Terlebih lagi, mereka sering dengan sengaja menghalangi manusia dari jalan Allah. Juga disebabkan karena mereka memakan riba dengan terangterangan. Padahal sudah dijelaskan bahwa perilaku tersebut telah dilarang. Selain itu, mereka juga memakan harta benda orang lain dengan cara yang tidak dibenarkan. Oleh karena itu, Allah telah menyediakan untuk orang-orang kafir dan berbuat aniaya tersebut mendapat siksa yang pedih. ${ }^{20}$

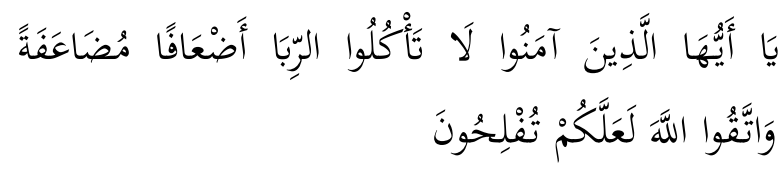

"Hai orang-orang yang beriman, janganlah kamu memakan riba dengan berlipat gandadan bertakwalah kamu kepada Allah supaya kamu mendapat keberuntungan.” QS. Ali Imran: 130

Pada tahap ketiga, peringatan Allah dalam Alquran mengenai riba yang berlipat ganda. Riba yang diharamkan dengan dikaitkan kepada suatu tambahan yang berlipat ganda. Para ahli tafsir berpendapat, bahwa pengambilan bunga dengan tingkat yang cukup tinggi merupakan fenomena yang banyak dipraktekkan pada masa tersebut. ${ }^{21}$

Ayat tersebut menegaskan kepada orang-orang yang beriman. Penegasan perintah dan larangan utuk tidak memakan riba. Terlebih lagi apabila riba tersebut berlipat ganda. Riba disini ialah riba nasi'ah. Menurut sebagian besar ulama bahwa riba nasi'ab selamanya hukumnya haram, meskipun tidak berlipat ganda. Oleh karena itu, Allah memberikan perintah kepada orang-orang beriman supaya bertakwa dengan jalan meninggalkan riba tersebut. Dengan begitu, mereka yang taat akan mendapatkan keberuntungan. $^{22}$
${ }^{17}$ Zainuddin Ali, Op., Cit, hal. 100.

${ }^{18}$ Dwi Suwiknyo, Op.,Cit, hal. 38-39.

19 Zainuddin Ali, Op., Cit, hal. 100

\footnotetext{
${ }^{20}$ Dwi Suwiknyo, Op.,Cit, hal. 40-41

${ }^{21}$ Zainuddin Ali, OP.,Cit, hal. 100-101
}

22 Dwi Suwiknyo, Op., Cit, hal. 42-43. 


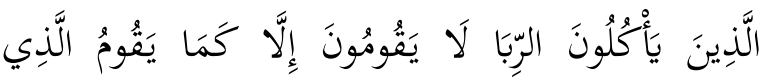

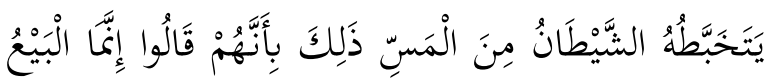

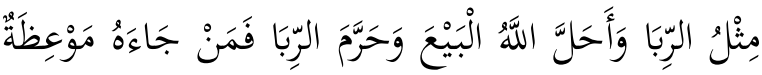

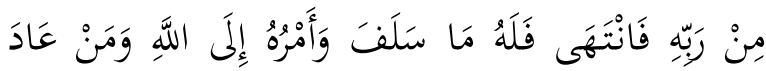

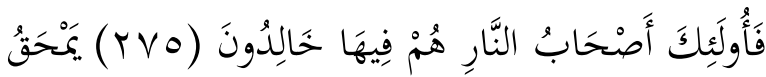

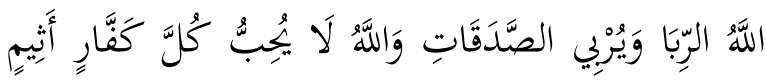

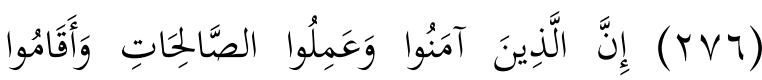

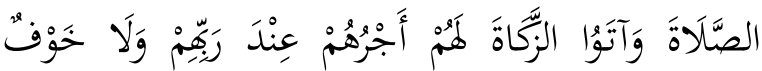

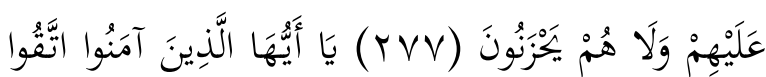

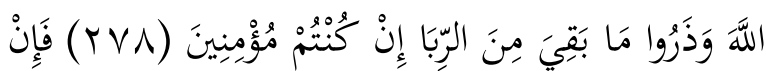

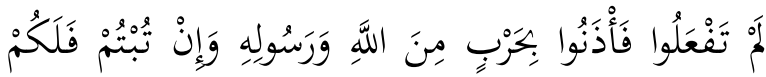

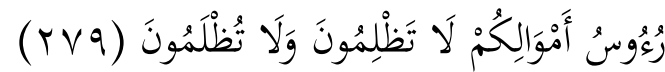

Orang-orang yang makan (mengambil) riba tidak dapat berdiri melainkan seperti berdirinya orang yang kemasukan syaitan lantaran (tekanan) penyakit gila. Keadaan mereka yang demikian itu, adalah disebabkan mereka berkata (berpendapat), Sesunggubnya jual beli itu sama dengan riba. Padahal Allah telah menghalalkan jual beli dan mengharamkan riba.Orang-orang yang telah sampai kepadanya larangan dari Tuhannya, lalu terus berhenti (dari mengambil riba), maka baginya apa yang telah diambilnya dabulu (sebelum datang larangan); dan urusannya (terserah) kepada Allah. Orang yang kembali (mengambil riba), maka orang itu adalah penghuni-penghuni neraka; mereka kekal di dalamnya. 275. Allab memusnabkan riba dan menyuburkan sedekah dan Allah tidak menyukai setiap orang yang tetap dalam kekeafiran dan selalu berbuat dosa. 276.Sesunggubnya orang-orang yang beriman, mengerjakan amal saleh, mendirikan shalat dan menunaikan zakat, mereka mendapat pahala di sisi Tubannya. tidak ada kekhawatiran terhadap mereka dan tidak (pula) mereka bersedih hati. 277.Hai orang-orang yang beriman, bertakwalah kepada Allah dan tinggalkan sisa riba (yang belum dipungut) jika kamu orang-orang yang beriman. 278.Maka jika kamu tidak mengerjakan (meninggalkan sisa riba), maka ketabuilah, bahwa Allab dan Rasul-Nya akan memerangimu.Dan jika kamu bertaubat (dari pengambilan riba), maka bagimu pokok hartamu; kamu tidak menganiaya dan tidak (pula) dianiaya. 279. QS. Al-Baqarah: 275279.

Pada tahap keempat atau terakhir, peringatan Allah SWT dalam Alquran sebagai peringatan terakhir mengenai riba secara jelas dan tegas mengharamkan riba dalam berbagai jenis tambahan yang diambil dari pinjaman. ${ }^{23}$

Ayat tersebut akan sempurna untuk dijelaskan jika diketahui asbabun nuгul-nya. Abu Ja'far Muhammad bin Jarir ath-Thabari meriwayatkan, "Kaum Tsaqif, penduduk kota Thaif, telah membuat suatu kesepakatan dengan Rasulullah SAW bahwa semua utang mereka, demikian juga piutang (tagihan) mereka yang berdasarkan riba agar dibekukan dan dikembalikan hanya pokoknya saja. Setelah Fathul Makkah, Rasulullah SAW menunjuk Itab bin Usaid sebagai Gubernur Mekah yang juga meliputi kawasan Thaif sebagai daerah administrasinya. Bani Amr bin Umair bin Auf adalah orang yang senantiasa meminjamkan uang secara riba kepada Bani Mughirah dan sejak zaman Jahiliyyah Bani Amr Mughirah senantiasa membayarnya dengan tambahan riba. ${ }^{24}$

Setelah kedatangan Islam, mereka tetap memiliki kekayaan dan asset yang banyak. Karenanya, datanglah Bani Amr untuk menagih utang dengan tambahan riba dari Bani Mughirah seperti sediakala- tetapi Bani Mughirah setelah memeluk Islam menolak untuk memberikan tambahan riba tersebut. Dilaporkanlah masalah tersebut kepada Gubernur Itab bin Usaid. Menanggapi masalah ini, Guberrnur Itab langsung menulis surat kepada Rasulullah SAW dan turunlah ayat tersebut. Rasulullah SAW lantas menulis surat balasan kepada Gubernur Itab, "Jika mereka ridha atas ketentuan Allah di atas, maka itu baik. Tetapi jika mereka menolaknya maka

23 Zainuddin Ali, Op., Cit, hal. 101.

${ }^{24}$ Dwi Suwiknyo, Op.,Cit, hal. 44. 
kumandangkanlah ultimatum perang kepada mereka." 25

Berdasarkan kepada asbabun nuгul tersebut, maka Allah memerintahkan kepada seluruh orang yang beriman untuk meninggalkan sisa riba dari setiap piutang. ${ }^{26}$ Allah mengutuk keras orang yang mengambil riba, menegaskan perbedaan yang jelas antara perniagaan dan riba dan menuntut kaum muslimin agar menghapuskan seluruh utang piutang yang mengandung riba, menyerukan mereka agar mengambil pokoknya saja dan mengikhlaskan kepada peminjam yang mengalami kesulitan. ${ }^{27}$ Perintah tersebut akan menunjukkan siapa yang benar-benar orang yang beriman dan bertakwa. Jika benar-benar masih melakukan transaksi riba maka Allah dan Rasul-Nya akan memerangi mereka. Karenanya, tidak bertraksaksi lagi dengan riba, namun tetap mendapatkan hak kembali atas setiap piutang, yakni pokok hartaya saja. Perintah tersebut merupakan keadilan sosial supaya tidak ada manusia yang menganiaya dan dianiaya. ${ }^{28}$

Dalam ayat-ayat di atas secara jelas dan tegas menunjukkan tentang hukum haramnya riba, bahkan dalam ayat ini mengancam siapasiapa yang masih melakukannya akan diperangi oleh Allah dan Rasul-Nya. Jadi, riba diharamkan dalam Alquran secara bertahap. Mulanya diturunkan ayat QS.ar Ruum: 39 yang berisi pendahuluan untuk pengharaman. Senjutnya dalam QS.ar Ruum: 161 diberikan peringatan mengharamkan. Selanjutnya dalam QS. Ali Imran: 130 dilarang riba yang keji, yang bertambah hingga menjadi berlipat ganda. Setelah itu datanglah ayat pengharaman secara pasti dari riba yakni QS.al Baqarah: 278. Ketentuan surat al Baqarah: 275-279 yang dimulai dengan penjelasan ayat-ayat infak dan diakhiri ancaman yang keras terhadap pemakan harta riba. QS. Al Baqarah: 275-279, ayat ini mengandung penolakan tegas terhadap orang yang mengatakan bahwa riba tidak haram kecuali jika berlipat ganda, karena Allah tidak membolehkan kecuali mengembalikan modal pokok tanpa ada pertambahan. QS. Al Baqarah: 275-279 merupakan ayat terakhir berkaitan dengan riba. ${ }^{29}$

Berdasarkan pembahasan tersebut, konsep anti riba dalam Alquran melalui tahapan pertama, menggambarkan adanya unsur negatif di dalamnya. Kedua, berisi isyarat tentang keharamannya. Ketiga, dinyatakan secara eksplisit keharaman dari salah satu bentuknya. Tahap keempat, diharamkan secara total dalam berbagai bentuknya. ${ }^{30}$

\section{$\underline{\text { Hadis }}$}

Pelarangan riba dalam hukum Islam tidak hanya merujuk kepada Alquran melainkan juga ditemukan dasar hukum di dalam hadis Rasulullah SAW. Posisi umum hadis terhadap Alquran adalah menjelaskan aturannya tentang pelarangan riba secara rinci. $^{31}$

Terdapat beberapa hadis yang mejelaskan tentang riba, antara lain adalah sebagai berikut:

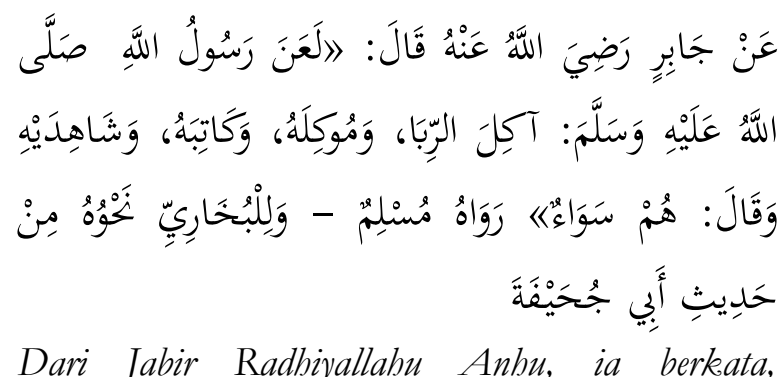
"Rasulullab Shallallabu Alaibi wa Sallam melaknat pemakan riba, pemberi makan riba, penulisnya, dan dua orang saksinya. Lalu beliau bersabda, "Mereka

${ }^{25}$ Ibid., hal. 45.

${ }^{26}$ Ibid., hal. 46.

27 Ascarya, Akad \& Produk Bank Syariah.(Jakarta: PT. Raja Grafindo Persada, 2008), hal. 14.

$$
{ }^{28} \text { Op., Cit, hal. 44-46. }
$$


itu sama." (HR. Riwayat Muslim. Al-Bukbari juga meriwayatkan hadis semisal dari Abu Jubaifab). ${ }^{32}$

Dalam hadis ini, Nabi SAW mendo'akan kepada para pelaku riba sebagaimana yang disebutkan dalam hadis agar dijauhkan dari rahmat Allah. Hal ini menunjukkan adanya dosa bagi para pelaku riba dan dalil haramnya melakukan transaksi riba. Terlebih bagi pemakan riba, karena dialah yang langsung memanfaatkannya dibandingkan dengan yang lain. Maksud orang yang memberi makan riba yaitu orang yang memberi riba, karena transaksi riba ini tidak akan terjadi tanpa adanya perantara darinya, sehingga ia masuk juga dalam kubangan dosa. Sedangkan penulis dan kedua saksi dalam transaksi riba mendapatkan dosa juga disebabkan karena mereka turut serta dalam membantu perbuatan terlarang. Hal ini berlaku jika dilakukan dengan sengaja dan mengetahui bahwa ia telah melakukan perbuatan riba. Dalam riwayat hadits, disebutkan penggunaan kata 'syahid' (saksi) yang dilaknat dengan kata tunggal, hal ini dimaksudkan untuk penyebutan jenisnya.

وَعَنْ عُبَادَةَ بْنِ الصَّامِتِ قَالَ: قَالَ رَسُولُ اللَّهِ صَلَّى اللَّهُ

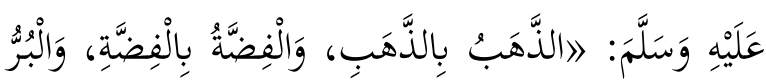

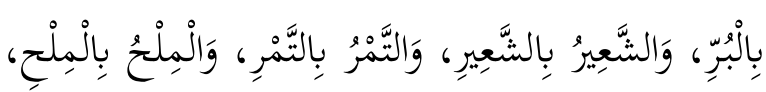

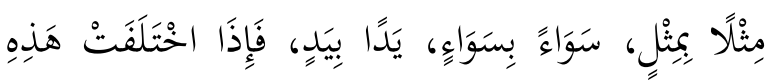

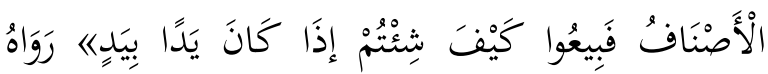

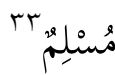

Dari Ubadah bin Ash-Shamit Radbiyallahu Anbu bahwa Rasulullah Shallallabu Alaibi wa Sallam bersabda, "(Diperbolebkean menjual) emas dengan emas, perak dengan perak, gandum dengan gandum, sya'ir dengan sya'ir, kurma dengan kurma, garam dengan garam, sama sebanding, sejenis, dan ada serab terima dan jika jenis-jenisnya berbeda maka juallah sesuai dengan kehendak kalian dengan syarat kontan."(HR. Muslim).

${ }^{32}$ Muhammad bin Ismail al Amir ash Shan'ani, Subulus Salam, Op.,Cit, hal. 394.

${ }^{33}$ Ibid., hal. 398.
وَعَنْ عَبْدِ اللَّهِ بْنِ مَسْعُودٍ رَضِيَ اللَّهُ عَنْهُ - عَنْ النَّبيّ

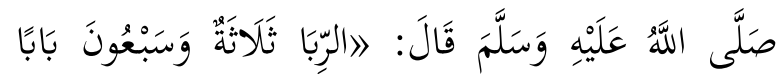

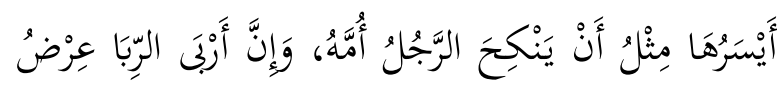

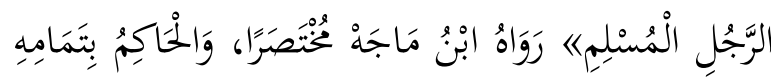
وَصَحَّحَحُهُ

Dari Abdullab Ibnu Mas'ud Radhiyallabu Anbu, dari Nabi Shallallahu Alaibi wa Sallam bersabda, "Riba itu mempunyai 73 pintu, yang paling ringan ialab seperti seorang laki-laki yang menikabi ibunya dan riba yang paling berat ialah merusak kehormatan seorang muslim." (HR. Ibnu Majab dengan ringkas, dan Al-Hakim meriwayatkannya dengan lengkap, dan menurutnya hadis itu shabib).

Dalam hadis tersebut terdapat dalil riba secara mutlak berupa perbuatan yang diharamkan walaupun tidak terdapat dalam pintu-pintu riba yang sudah dikenal. Gambaran riba yang paling ringan bagaikan seorang lakilaki menikahi ibunya sendiri karena secara akal hal tersebut sangatlah nista.

\section{KLASIFIKASI RIBA MENURUT ULAMA MAZHAB}

Riba tidak hanya satu macam, tetapi bermacam-macam sesuai dengan sifat dan tujuan transaksi. Umumnya terjadi, karena adanya tambahan dalam pertukaran, baik karena penundaan atau barang yang serupa. Diharamkannya riba yang terjadi pada tambahan tanpa imbalan, umumnya karena orang yang berakal, biasanya tidak mau memberikan tambahan, kecuali karena keadaan terdesak, sehingga di saat seperti itu terjadilah pemerasan yang terlarang oleh Islam. ${ }^{35}$

Jumhur ulama membagi riba dalam dua bagian, yaitu riba fadbl dan riba nasi'ab. ${ }^{36}$ Pertama, Riba Fadbl. Fadhl berarti kelebihan yang dikenakan dalam pertukaran atau penjualan barang yang sama jenisnya atau

34 Ibid., hal. 396.

${ }^{35}$ Abu Sura'i Abdul Hadi, OP.,Cit, hal. 27.

${ }^{36}$ Rachmat Syafe'I, Fiqih Muamalah, (Bandung: CV. Pustaka Setia, 2001), hal. 262. 
bentuknya (umpamanya gandum, padi, lembu, kambing, dsb). ${ }^{37}$ Menurut ulama Hanafiyah, riba fadhl adalah: tambahan zat harta pada akad jual beli yang diukur dan sejenis. Dengan kata lain, riba fadbl adalah jual beli yang mengandung unsur riba pada barang sejenis dengan adanya tambahan pada salah satu benda tersebut. Oleh karena itu, jika melaksanakan akad jual beli antar barang yang sejenis, tidak boleh dilebihkan salah satunya agar terhindar dari unsur riba. ${ }^{38}$

Menurut Fuqaha, unsur-unsur riba fadbl adalah sebagai berikut: ${ }^{39}$

1. Kedua barang yang dipertukarkan adalah homogen atau sejenis, seperti emas dengan emas, jagung dengan jagung.

2. Jumlah keduanya berbeda dalam timbangan maupun takaran. Jika emas dipertukarkan dengan emas dan jumlah serta kualitasnya sama serta tunai, maka itu bukan riba (bunga). Jika tidak sama, maka kelebihannya pasti bunga.

3. Transaksi itu mestilah tidak berlangsung tunai. Jika satu guinea diberikan sebagai imbalan bagi satu setengah guinea di masa yang akan datang, maka kelebihannya itu adalah riba (bunga).

Kedua, Riba Nasi'ah. Nasi'ab berarti penundaan waktu untuk membayar yang diberikan kepada si pengutang. ${ }^{40}$ Menurut ulama Hanafiyah, riba nasi'ab adalah: memberikan kelebihan terhadap pembayaran dari yang ditangguhkan, memberikan kelebihan pada benda dibanding utang pada benda yang ditakar atau ditimbang yang berbeda jenis atau selain dengan yang ditakar dan ditimbang yang sama jenisnya.

${ }^{37}$ Muhammad Muslehuddin, Sistem Perbankan dalam Islam, (Jakarta: PT. Rineka Cipta, 2004), hal. 30.

${ }^{38}$ Rachmat Syafe'i, Op., Cit, hal. 262.

${ }^{39}$ Muhammad Sharif Chaudry, Sistem Ekonomi Islam: Prinsip Dasar terjemahan Fundamental of Islamic Economic System, (Jakarta: Kencana Prenada Media Group, 2012), hal. 224.

${ }^{40}$ Muhammad Muslehuddin, Op., Cit, hal. 80.
Maksudnya, menjual barang dengan sejenisnya tetapi yang satu lebih banyak, dengan pembayaran diakhirkan, seperti menjual satu kilogram gandum dengan satu setengah kilogram gandum, yang dibayarkan setelah dua bulan. Contohnya jual beli yang tidak ditimbang, seperti membeli satu buah semangka dengan dua buah semangka yang akan dibayar setelah sebulan. ${ }^{41}$

Menurut para fuqaha, riba nasi'ah mengandung tiga elemen berikut: ${ }^{42}$

1. Kelebihan dari utang pokok.

2. Menentukan besarnya kelebihan tersebut dalam hubungannya dengan waktu.

3. Kelebihan tersebut menjadi syarat berlangsungnya transaksi pinjaman.

Ibn Abbas, Usamah Ibn Jaid Ibn Arqam, Jubair, Ibn Jabir, dal lain-lain berpendapat bahwa riba yang diharamkan hanyalah riba nasi'ah. Pendapat ini didasarkan pada hadis yang diriwayatkan oleh Bukhari dan Muslim bahwa Rasulullah SAW bersabda:

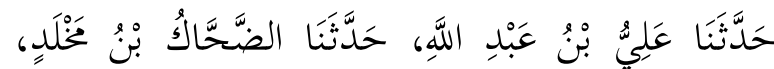

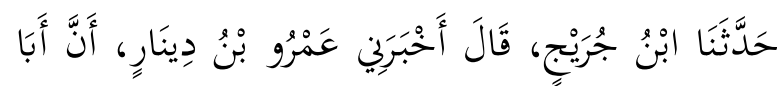

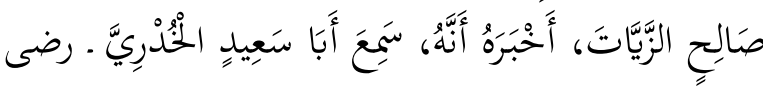

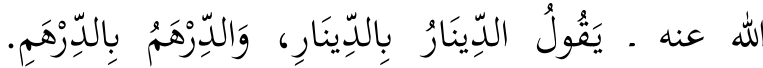

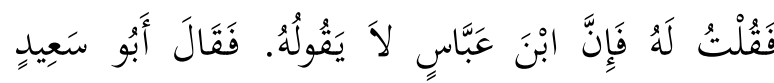

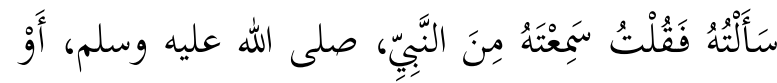

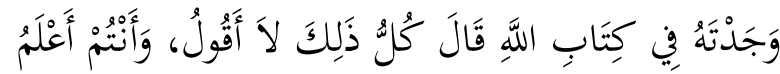

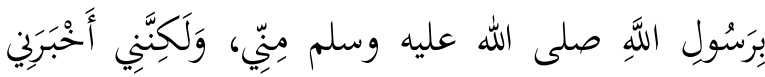

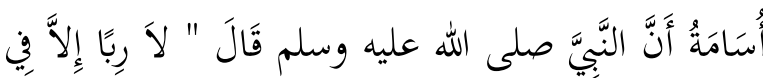

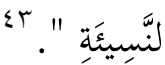

Telah menceritakan kepada kami 'Ali bin 'Abdullah telah menceritakan kepada kami Adh Dhabhak bin Makblad telah menceritakan kepada kami Ibnu Juraij berkata, telah mengabarkan kepada saya

\footnotetext{
${ }^{41}$ Rachmat Syafe'I, Op., Cit, hal. 262-263.

${ }^{42}$ Muhammad Sharif Chaudry, Op., Cit, hal. 223.

${ }^{43}$ Sahih Bukhari (2179) dan Muslim (1596) tentang Jual Beli.
} 
'Amru bin Dinar bahwa Abu Shalih Az. Zayyat mengabarkan kelpadanya babwa dia mendengar Abu Sa'id Al Kbudriy radliallabu 'anbu berkata: "Dinar dengan dinar dan dirbam dengan dirbam". Aku berkata kepadanya babwa Ibnu 'Abbas radliallabu 'anbuma tidak mengatakan seperti itu. Maka Abu Sa'id berkata: "Aku pernab bertanya kepadanya dimana aku katakan apakah kamu mendengarnya dari Nabi shallallabu 'alaibi wasallam atau kamu mendapatkan keterangannya dari Kitab Allah? Maka dia menjawab: "Semuanya itu aku tidak pernah mengatakannya. Dan kalian lebih mengetabui Rasulullah shallallahu 'alaibi wasallam daripada aku namun Usamah mengabarkan kepadaku bahwa Nabi shallallahu 'alaibi wasallam berkata: "Tidak ada riba, kecuali riba' nasi'ab" (riba dalam urusan pinjam meminjam dengan ada tambahan).

Sedangkan ulama Syafi'iyah membagi riba menjadi tiga jenis.Pertama, Riba Fadbl. Riba fadbl adalah jual beli yang disertai adanya tambahan salah satu pengganti (penukar) dari yang lainnya. Dengan kata lain, tambahan berasal dari penukar paling akhir. Riba ini terjadi pada barang yang sejenis, seperti menjual satu kilogram kentang dengan satu setengah kilogram kentang.

Kedua, Riba Yad. Yaitu Jual beli dengan mengakhirkan penyerahan (al qabdu), yakni bercerai-berai antara dua orang yang akad sebelum timbang terima, seperti menganggap sempurna jual beli antara gandum dengan sya'ir tanpa harus saling menyerahkan dan menerima di tempat akad.

Ketiga, Riba Nasi'ah. Riba nasi'ab yakni jual beli yang pembayarannya diakhirkan, tetapi ditambah harganya. Menurut ulama Syafi'iyah, riba yad dan riba nasi'ab sama-sama terjadi pada pertukaran barang yang tidak sejenis. Perbedaannya, riba yad mengakhirkan pemegangan barang, sedangkan riba nasi'ah mengakhirkan hak dan ketika akad dinyatakan bahwa waktu pembayaran diakhirkan meskipun sebentar. Al-Mutawalli menambahkan, jenis riba dengan riba qurdi (mensyaratkan adanya manfaat). Akan tetapi, Zarkasyi menempatkannya pada riba fadbl. ${ }^{44}$

\section{RIBA DALAM KOMPILASI HUKUM EKONOMI SYARI'AH (KHES)}

Kompilasi Hukum Ekonomi Syari'ah tersusun dari kata "kompilasi" dan "Hukum Ekonomi Syari'ah". Kata "kompilasi" diambil dari bahasa Inggris "compilation" atau bahasa Belanda "compilatie" yang berarti menyusun, mengumpulkan, menghimpun. Kompilasi diartikan kumpulan yang tersusun secara teratur. ${ }^{45}$ Menurut Webster's World University mendefinisikan kompilasi yaitu mengumpulkan bahan-bahan yang tersedia ke dalam bentuk yang teratur seperti dalam bentuk buku, mengumpulkan berbagai jenis data. ${ }^{46}$

Sedangkan Hukum Ekonomi Syari'ah merupakan aturan yang mengatur segala perbuatan atau kegiatan usaha yang dilaksanakan menurut prinsip syari'ah yang bersumber dari hukum Islam yang berlaku. ${ }^{47}$ Jadi, Kompilasi Hukum Ekonomi Syari'ah (KHES) merupakan kumpulan yang teratur dari aturan yang mengatur segala perbuatan atau kegiatan usaha yang dilaksanakan menurut prinsip syari'ah yang bersumber dari hukum Islam yang berlaku.

Lahirnya Undang-Undang Nomor 3 Tahun 2006 tentang perubahan atas UndangUndang Nomor 7 tahun 1989 tentang Peradilan Agama telah membawa perubahan besar terhadap kedudukan dan eksistensi Peradilan Agama di Indonesia. Di samping kewenangan yang telah diberikan dalam bidang hukum keluarga Islam, Peradilan Agama juga

\footnotetext{
${ }^{44}$ Rachmat Syafe'i, Op., Cit, hal. 262-264.

45 Departemen Pendidikan Nasional, Kamus Besar Bahasa Indonesia, (Jakarta: Balai Pustaka, 2002), hal. 584.

46 Pratiwi dan Ahmad Rifai, Urgensi Pembentukan Kitab Undang-Undang Hukum Ekonomi Syariah Indonesia, Jurnal Syariah 4 (Juli 2016), hal. 91.

47 Zainuddin Ali, Hukum Ekonomi Syariah, (Jakarta: Sinar Grafika, 2008), hal. 2.
} 
diberi wewenang untuk menyelesaikan perkara dalam bidang ekonomi syari'ah yang meliputi perbankan syari'ah, lembaga keuangan mikro syari'ah, asuransi syari'ah, reasuransi syari'ah, reksadana syari'ah, obligasi syari'ah dan surat berharga berjangka menengah syari'ah, sekuritas syari'ah, pembiayaan syari'ah, pegadaian syari'ah, dana pensiunan lembaga keuangan syari'ah dan bisnis syari'ah. ${ }^{48}$

Mengenai hal riba, tidak ada satu konsep pun di dalam Kompilasi Hukum Ekonomi Syari'ah (KHES) yang membahas khusus tentang riba. Kata "riba" pun hanya sedikit yang dapat dijumpai di dalam Kompilasi Hukum Ekonomi Syari'ah (KHES). Berikut ini beberapa pasal yang menyebutkan riba secara eksplisit:

Pada pembahasan mengenai bai' murabahah pasal 116 dinyatakan bahwa: "Penjual harus membeli barang yang diperlukan pembeli atas nama penjual sendiri, dan pembelian ini harus bebas riba."

Di dalam pembahasan mengenai pasar modal bagian ke-2 tentang Emiten yang menerbitkan efek syari'ah pasal 576 (2) ((b)) "Lembaga Keuangan Konvensional disebut sebagai Lembaga Keuangan Ribawi."

Lalu masih pada pembahasan yang sama mengenai pasar modal bagian ke-3 tentang Transaksi Efek pasal 577 (1) dan (2) "Transaksi efek tidak boleh mengandung unsur dharar, gharar, riba, maisir, risywah, maksiat dan kezaliman." 50

Kemudian pada pembahasan mengenai Reksadana Syari'ah bagian ke-3 tentang Pemilihan dan Pelaksanaan Investasi pasal 585 (2) (b)) "Usaha Lembaga Konvensional/ribawi." $" 51$

48 PPHIMM, Kompilasi Hukum Ekonomi Syari'ah (Edisi Revisi), (Jakarta:Kencana, 2009), hal. 253.

49 Lihat pasal 576 ayat (2) ((b)) Kompilasi Hukum Ekonomi Syari'ah.

${ }^{50}$ Lihat pasal 577 ayat (1) dan (2) Kompilasi Hukum Ekonomi Syari'ah.

51 Lihat pasal 585 ayat (2) ((b)) Kompilasi Hukum Ekonomi Syari'ah.
Kata "riba" di dalam KHES hanya disebutkan sebagaimana yang terdapat dalam pasal-pasal tersebut, tidak ada pembahasan khusus mengenai riba. Meskipun demikian, KHES secara eksplisit dan implisit tetap mengharamkan akad-akad yang di dalamnya mengandung unsur riba. Hal ini juga tercermin dari adanya asas akad yang antara lain: saling menguntungkan, iktikad baik, sebab yang halal, dan sebagainya yang mana asas-asas tersebut mendukung adanya pelarangan riba secara implisit.

Ada beberapa alasan pembahasan riba yang secara implisit tidak dituangkan dalam bentuk pasal per pasal di dalam Kompilasi Hukum Ekonomi Syari'ah (KHES). KHES membahas tentang akad-akad dalam mu'amalah. Sedangkan riba bukanlah merupakan suatu akad. Tidak ada akad riba, di dalam mu'amalab hanya terdapat akad syirkah, akad mudharabah, akad jual beli dan lain sebagainya. Riba merupakan suatu unsur yang terdapat di dalam sebuah transaksi dan merupakan unsur yang dilarang. Jika terdapat unsur riba dalam suatu transaksi mu'amalah, maka dapat diajukan ke Pengadilan Agama sebagai suatu perkara Ekonomi Syari'ah sebab Pengadilan Agama berwenang dalam penyelesaian sengketa tersebut. $^{52}$

KHES mengadopsi sebagian kitab Majallah al Abkam al 'Adliyyah. Majallah al Abkam al 'Adliyyah merupakan kitab undangundang hukum perdata Islam pertama yang dikodifikasi pada tahun $1293 \mathrm{H} / 1876 \mathrm{M}$ oleh pemerintah Turki Utsmani. Kitab ini mengatur dan membahas masalah muamalat menurut Islam dan memuat sedikit tentang hukum peradilan yang terdiri dari sebuah muqaddimah dan 16 kitab dan diuraikan dalam 1851 pasal yang disusun dengan sistematika kitab hukum modern. Kitab ini tidak hanya berlaku di Turki Utsmani saja, tetapi juga di beberapa Negara Islam yang berada di bawah kekuasaannya

52 Drs. H. Edi Riadi, SH, MH, Wawancara Pribadi via telepon pada 23-3-2018. 
seperti Yordania, Suriah dan Lebanon. Dan masa berlakunya berakhir pada tahun 1926 ketika Kamal Attaturk berhasil menghapus hukum Islam sebagai agama resmi Negara dengan program sekulerisasinya ${ }^{53} \mathrm{Di}$ dalam kitab Majallat al Ahkam al 'Adliyyah Turki Utsmani juga tidak ada pembahasan terkait riba ataupun bunga. Sehingga, KHES yang mengadopsi kitab Majallat al Ahkam al 'Adliyyah Turki Utsmani juga tidak ada pembahasan terkait riba ataupun bunga. ${ }^{54}$

Terhindar dari riba merupakan prinsip transaksi/akad dalam syari'ah. Posisinya sejajar dengan gharar, maisir dan dharar yang harus dihindari. Sebaliknya prinsip positif dalam transaksi yaitu al 'adalah, al musawah, dll. Prinsip akad memang tidak mesti dinyatakan secara eksplisit, selama akad-akad yang diatur dipenuhi dhawabith dan bududnya, maka riba wa akbwatubu akan terhindar dengan sendirinya. ${ }^{55}$ Alasan ini menunjukkan bahwa selama terpenuhi dhawabith dan budud dari akad-akad yang dilakukan, maka akad tersebut dengan sendirinya akan terhindar dari riba. Sehingga tidak perlu lagi adanya pembahasan khusus mengenai riba di dalam KHES.

Bahwa di dalam khazanah hukum Islam atau fikih sudah dibicarakan/dibahas secara mendalam dan luas, sehingga dirasa tidak perlu lagi dimunculkan (dibahas secara khusus) di dalam KHES. ${ }^{56}$ Alasan ini mengisyaratkan bahwa konsep tentang riba telah diketahui secara umum di tengah-tengah masyarakat karena telah banyak pembahasan terkait riba di dalam ajaran fikih mu'amalah. Diharapkan para pengkaji hukum Islam terutama bagi para hakim di Pengadilan Agama mengerti, memahami dan mengamalkan dengan meninggalkan riba tersebut.

\section{KESIMPULAN}

Dari pembahasan dan analisa yang sudah di jelaskan di atas, maka dapat disimpulkan bahwa di dalam KHES tidak ada pembahasan khusus mengenai riba, seperti halnya pasal per pasal. Meskipun demikian, KHES secara eksplisit dan implisit tetap mengharamkan akad-akad yang di dalamnya mengandung unsur riba. Hal itu disebabkan karena ada beberapa pertimbangan, antara lain; KHES membahas tentang akad-akad dalam mu'amalah. Sedangkan riba bukanlah merupakan suatu akad, KHES mengadopsi sebagian kitab Majallah al Abkam al 'Adliyyah. Majallah al Abkam al 'Adliyyah Turki Utsmani karenanya juga tidak ada pembahasan terkait riba ataupun bunga, Terhindar dari riba merupakan prinsip transaksi/akad dalam syari'ah. Posisi riba sejajar dengan gharar, maisir dan dharar yang juga harus dihindari. Bahwa di dalam khazanah hukum Islam atau fikih sudah dibicarakan/dibahas secara mendalam dan luas, sehingga dirasa tidak perlu lagi dimunculkan (dibahas secara khusus) di dalam KHES.
53 Zulkarnain Abdurrahman, Keberadaan Majallat al Ahkam al 'Adliyah dalam Perkembangan Hukum Islam, pmi.uinsu.ac.id/berita/read/132/keberadaan-majallatal-ahkam-al-adliyah-dalam-perkembangan-hukumislam.html diakses pada Senin 16 Juli 2018.

54 Dr. H. Anton Athoillah, MM, Wawancara Pribadi, via Whatsapp pada 15-7-2018.

55 Prof. Dr. Jaih Mubarok, M. Ag, Wawancara Pribadi, via Whatsapp pada 17-7-2018.

56 Bapak Drs. H. Farid Ismail, SH, MH, Wawancara Pribadi, via Facebook. 


\section{DAFTAR KEPUSTAKAAN}

Muhammad bin Ismail Al-Amir Ash-Shan'ani, Subulus Salam Syarah Bulughul Maram, penerj. Muhammad Isnan, dkk, Jakarta: Darus Sunnah Press, 2012, cet. ke-7

Ahmad Sarwat, Kitab Mu'amalat, [t.tp]: Kampus Syari'ah, 2009).

Abdul Rahman Ghazaly, dkk, Figh Mu'amalat, Jakarta: Kencana Prenada Media Group, 2012, cet. $\mathrm{Ke}-2$

Zainuddin Ali, Hukum Ekonomi Syari'ah, Jakarta: Sinar Grafika, 2008

PPHIMM, Kompilasi Hukum Ekonomi Syari'ah, Jakarta: Kencana Prenada Media Group, 2009

Abd. Shomad, Hukum Islam: Penormaan Prinsip Syariah dalam Hukum Indonesia Edisi Revisi, Jakarta: Kencana Prenada Media Group, 2012

Zainuddin Ali, Hukum Perbankan Syariah, Jakarta: Sinar Grafika, 2010

Abu Sura'i Abdul Hadi, Bunga Bank dalam Islam terjemahan dari Ar Riba wal Qurudl, Surabaya: Al Ikhlas, 1993

Muhammad bin Ismail al Amir ash Shan'ani, Subul al-Salam Syarah Bulughul Maram, penerj. Muhammad Isnan, dkk, Jakarta: Darus Sunnah Press, 2012

Dwi Suwiknyo, Kompilasi Tafsir Ayat-Ayat Ekonomi Islam, Yogyakarta: Pustaka Pelajar, 2010

Ascarya, Akad \& Produk Bank Syari'ah,Jakarta: PT. Raja Grafindo Persada, 2008

Rachmat Syafe'I, Fiqih Muamalah, Bandung: CV. Pustaka Setia, 2001

Muhammad Muslehuddin, Sistem Perbankan dalam Islam, Jakarta: PT. Rineka Cipta, 2004

Muhammad Sharif Chaudry, Sistem Ekonomi Islam: Prinsip Dasar terjemahan Fundamental of Islamic Economic System, Jakarta: Kencana Prenada Media Group, 2012

Departemen Pendidikan Nasional, Kamus Besar Bahasa Indonesia, Jakarta: Balai Pustaka, 2002 Pratiwi dan Ahmad Rifai, Urgensi Pembentukan Kitab Undang-Undang Hukum Ekonomi Syariah Indonesia, Jurnal Syariah 4 Juli 2016

Zainuddin Ali, Hukum Ekonomi Syari'ah, Jakarta: Sinar Grafika, 2008

PPHIMM, Kompilasi Hukum Ekonomi Syari'ah (Edisi Revisi), Jakarta: Kencana, 2009 
Kompilasi Hukum Ekonomi Syari’ah.

Drs. H. Edi Riadi, SH, MH, Wawancara Pribadi via telepon pada 23-3-2018.

Zulkarnain Abdurrahman, Keberadaan Majallat al Abkam al 'Adliyah dalam Perkembangan Hukum Islam, http: pmi.uinsu.ac.id/berita/read/132/keberadaan-majallat-al-ahkam-al-adliyah-dalamperkembangan-hukum-islam.html diakses pada Senin 16 Juli 2018.

Dr. H. Anton Athoillah, MM, Wawancara Pribadi, via Whatsapp pada 15-7-2018

Prof. Dr. Jaih Mubarok, M. Ag, Wawancara Pribadi, via Whatsapp pada 17-7-2018.

Bapak Drs. H. Farid Ismail, SH, MH, Wawancara Pribadi, via Facebook. 